\title{
Research on the Development Strategies of Cross- border E-business Intelligent Logistics in Fujian
}

\author{
Zhongwei Huang \\ Fuzhou University of International Studies and Trade, 350202
}

\begin{abstract}
Logistics is closely related to e-business. Based on the current development status of cross-border e-business, from the perspective of market scale and political environment, this paper analyzes the influence of intelligent logistics on crossborder e-business through taking intelligent logistics as the cutting point, then finds out there are problems in the process for Fujian cross-border e-business to utilize intelligent logistics, including low popularization of intelligent logistics, imperfect system, excessively dependence on cross-border giants, and lack of high-end professional intelligent logistics talents, and finally, it puts forward countermeasures from several aspects, including establishing oversea location, improving logistics informatization intelligence, and introducing and cultivating professional intelligent logistics talents.
\end{abstract}

Keywords-Intelligent logistics; Cross-border e-business and oversea location

\section{INTRODUCTION}

Logistics and e-business are closely related, and the prosperity of e-business has made intelligent logistics become the new favorite of e-business, and logistics can provide big support to cross-border e-business and is the big precondition for the continuous development of cross-border e-business. In economically advanced countries, such as Europe and America, logistics have had several decades of development histories. In America, logistics have been developed for about 100 years until this year. Under Internet+ era, cross-border e-business has been well developed, and it is time for cross-border logistics to step into the intelligence period. Intelligent logistics refer to using bar code, intelligent recognition technology, global positioning system and other advance technologies of the internet of things as well as information processing and network communication technology platform, to commonly use them in basic activity links such as the transportation of logistics industry, warehouse, distribution, package, loading and unloading, realize the automatic operation and highefficient optimization management in the goods transportation process, improve service level, reduce cost and decrease resource consumption.

\section{ANALYSIS OF CURRENT STATUS ABOUT THE} DEVELOPMENT OF CROSS-BORDER E-BUSINESS IN FUJIAN

\section{A. Market scale analysis}

By virtue of the good economic foundation, mature foreign trade operation environment, better industrial base, superior geological position and sound logistics system, Fujian Province has become the main force for national cross-border e-business In 2017, the cross-border e-business transaction volume in Fujian Province exceeded RMB 300 billion, the export of cross-border e-business kept above 35\% fast increase for three continuous years, and the transaction volume of cross-border ebusiness ranked the third nationwide [1]. The cross-border ebusiness enterprises in Fujian Province are mainly focused on Fuzhou, Xiamen, Quanzhou and other coastal cities, and as per the data statistics about the cross-border e-business public service platform in Fuzhou Province, in 2017, the accumulated order quantity for the import business of cross-border ebusiness in Fuzhou reached to 640,000 bills, which were increased by $136.71 \%$ on a year-on-year basis; the sales volume was RMB 210.41 million, which was increased by $124.09 \%$ on a year-on-year basis; and the import goods value was RMB 187.19 million, which was increased by $98.34 \%$ on a year-on-year basis.

\section{B. Political environment analysis}

In order to promote the development of cross-border ebusiness, Fujian Province has built favorable policy environments, and has successively released several policy measures, including the Notice of Fujian Provincial People's Government General Office about Accelerating 9 Measures of E-business Development, and encouraged and supported from establishing cross-border e-business park, platform construction support, tax preferences and other aspects[2]. In 2014, Fujian Free Trade Zone was approved and then in April next year, it was officially listed and established, and this had brought new opportunities for the fast development of crossborder e-business, of which Fuzhou District released the Implementation Methods about Promoting E-business Industry Development in Fuzhou Economic Technology Development Area (Trial) and the Settlement Conditions and Support Policies for the Cross-Border Trade E-Business Industry Center in Fuzhou Development Area. Pingtan District Park printed and issued the Notice about Further Promoting Crossborder E-business Development Action Plan, etc. In February, 2018, Department of Commerce of Fujian Province and other 
19 departments jointly issued a document, and actively cultivated the ecological circle of cross-border e-business; the Provincial Department of Commerce took lead in organizing customs, CIQ, electronic port and key cross-border e-business enterprises, and actively promoted the construction of crossborder e-business public service platform in the entire province.

\section{ANALYSIS OF THE INFLUENCE OF INTELLIGENT LOGISTICS ON CROSS-BORDER E-BUSINESS}

\section{A. Decrease logistics cost}

Cross-border logistics are necessary in cross-border ebusiness procedures, and cross-border e-business cannot be separated from cross-border logistics, while intelligent logistics can achieve the objective of reducing logistics expenses for suppliers and the final consumers through the mutual assistance and information sharing of intelligent logistics. Especially the application of new technologies in intelligent logistics, which can conduct intelligent management and control on the crossborder logistics process, and make the operation of logistics system more scientific and reasonable, reduce logistics loss, improve efficiency, decrease cost, and create more profits for enterprises. It can be seen that, intelligent logistics can effectively decrease the cross-border e-business cost and improve profits.

\section{B. Improve user experience}

Take Cainiao network platform subordinated to Alibaba as an example, there will be a sensor on the goods conveyor belt within every certain distance inside Cainiao automatic warehouse, and it can recognize the bar code on the paper box, and decide the next direction of the paper box, and can also support route combination and distribution, and the package corresponding to the order will be conveyed to the respective goods shelf and loaded with products; while the traditional mode refers to using manpower to select products from the goods shelf. The automatic scheme has largely improved the working conditions of sorters, and the package can be delivered outside of the warehouse within 10min; besides, this can also ensure that the goods are correctly installed. Moreover, there is also the automatic box sealing machine, which can improve the parcel packaging efficiency. Timeliness is one of the keys influencing the purchasing desire of clients, and high accuracy can bring extremely high clients' experience and decrease the correction cost.

\section{Meet the elastic demands of cross-border e-business}

Besides, specific to the elastic demands of e-business, for instance, during the Double Eleven, the warehouse may be out of stock, and may usually cause idle resources. There are obvious peak valley characteristics, and intelligent logistics can well adapt to that. Intelligent system can measure the hotselling products and unmarketable products, and through using this system, it can largely improve the warehouse handling capacity, and it can daily handle above one million goods, and such handling capacity can play its advantages during key periods, such as Double Eleven and Black Friday; after that, the warehouse utilization rate can still be ensured through intelligent dispatch. Refined operation is the future development trend of e-business, and it requires the promotion of intelligent logistics. Only intelligent logistics can realize better cooperation. The core for the refined operation of ebusiness is intelligent logistics, while refined operation is the future trend of e-business.

\section{Increase the purchasing confidence of purchasers}

Intelligent logistics can track vehicles in real time and also collect all the information during the entire goods distribution process through using new technologies and intelligent equipment, and can know about the location, status and other distribution information about the parcel, conduct tracking management on parcels, and provide immediate feedback about the logistics operation status for the consumers and managers. Specific to edible goods, it is also provided with food source querying service, and consumers can know about the source of goods through scanning or querying the official website, and this has improved the purchasing confidence of consumers and their second purchasing intention, and can also make the crossborder e-business market have a good circulation.

\section{ANALYSIS OF THE EXISTING PROBLEMS OF CROSS- BORDER E-BUSINESS INTELLIGENT LOGISTICS IN FUJIAN}

\section{A. The popularization rate of intelligent logistics is low and the system is imperfect}

Although under the influence of the Belt and Road Policy, Fujian Free Trade Zone has opened a gate for the development of cross-border e-business intelligent logistics. Fujian has also input lots of resources in constructing necessary facilities for cross-border e-business and the logistics system, but the basic facilities are still insufficient, and the logistics system hasn't been formed yet. Since cross-border logistics involve crossborder storage, cross-border customs clearance taxpaying, etc., the vehicles, warehouse and other basic logistic facilities, and also involve the necessary information infrastructure construction for cross-border logistics as well as the follow-up huge maintenance expenses. Besides, most cross-border ebusiness companies in Fujian are SMEs, while the high threshold and big input for independently building intelligent logistics have caused most enterprises in failing to utilize intelligent logistics to serve cross-border e-business, and most of them rely on manual means to select cross-border goods, so currently, the popularization rate for the application of intelligent logistics among cross-border e-business enterprises in Fujian is low, and the system hasn't been sound yet. Thus, in order to realize low-cost and high-efficient enterprise operation, cross-border e-business should have intelligent logistics facilities and reasonable logistics system.

\section{B. Rely on cross-border giants and utilize intelligent logistics}

Since the local cross-border e-business enterprises in Fujian are mostly SMEs, with small scale, and wide dispersion characteristics as well as the lack in strong capital strength to run intelligent logistics storage, the local cross-border ebusiness in Fujian Province will use the cross-border ebusiness industrial park established and operated in Xiamen or the advanced intelligent logistics device and management system of the cross-border e-business park in other districts; or 
select to rent the intelligent logistics warehouse established in the park from cross-border e-business giants. The cross-border e-business enterprises in Fujian can only rely on the logistics network founded by domestic cross-border giants at home and abroad as well as the import and export logistics solutions provided thereby for cross-border e-business. Thus, it is difficult to enjoy the low logistics cost brought by intelligent logistics storage and high-quality consumer service. As a whole, due to the small scale and insufficient strength of crossborder e-business in Fujian, they cannot serve the cross-border e-business of enterprises through relying on developing its own intelligent logistics, and through cooperating with big enterprises, it can use the intelligent logistics of big enterprises to serve itself.

\section{Lack of high-end professional intelligent logistics talents}

The blowout growth of cross-border e-business has caused the lack in lots of talents in such field and the surrounding relevant industries, of which insufficient talent conditions are most serious in the logistics industry.

Fujian Province also faces this problem, and although some colleges inside the province have set logistics specialty, but intelligent logistics are still the high-end version of logistics, and such high-tech post not only requires high-end professional intelligent logistics talents that can skillfully operate intelligent equipment but also know how to use software, especially IT talents. Fujian Province only has 6 universities setting master's degree program for logistics specialty, including Xiamen University, Jimei University, Fuzhou University and Minnan Normal University, and the quantity of students at school is about 600 people, which are far beyond the demand of logistics industry for intelligent logistics talents [3]. The professional intelligent logistics talent gap is big, and the talent supply is seriously insufficient, and cannot form powerful talent support for the development and utilization of cross-border intelligent logistics. Besides, except for the lack in high-end professional talents, the technical management talents in intelligent storage still face an extremely big gap. Due to the lack in high-quality talents corresponding to intelligent logistics and the storage talents that are important for intelligent logistics, the development and utilization of intelligent logistics for crossborder e-business in Fujian are still in a relatively low level.

\section{COUnTERmeasure Suggestions About Using} INTELLIGENT LOGISTICS TO DEVELOP THE CROSS-BORDER EBUSINESS IN FUJIAN

\section{A. The government guildes enterprises to raise funds and build oversea location}

Oversea location refers to the overseas warehouse established or rent abroad, and the goods are transported to the overseas warehouse through sea transportation, and it is mainly used in cross-border e-business. It is a mode for the crossborder e-business enterprises to firstly transport the products to be sold to the oversea location in batches, and then transfer the goods in the oversea location as per the order, and organize the delivery of goods. If Fujian cross-border e-business can use oversea location, they can enjoy all services in the entire process from the in-warehouse to the receiving of consumers.
Generally, oversea location will firstly intensively send goods to the overseas warehouse in advance, and then the overseas warehouse will send it to the consumers, and the logistics cost is lower than respectively sending single goods abroad. Taking the example of transporting $1 \mathrm{~kg}$ goods to America, the international small package of S.F. Express requires RMB 108 (7-12 days), and that for EMS requires RMB 118 (7-15 days). Besides, express companies can also charge RMB 1-10 handling expenses as per different weights. As for the expense for oversea location, it is generally composed of: the head range expense, storage expense, order handling expense, and the local distribution expense. Taking the example of transporting $1 \mathrm{~kg}$ goods to America through head range flights, if we assume the intensive transportation of 1,000 goods, and the total weight is $100 \mathrm{~kg}$, the single transportation expense is about RMB 10 in total, and the storage expense is RMB $0.05 /$ day-RMB 0.08/day, the handling expense is RMB 3-5, the local transportation expense is about RMB 20, and the total expense is about RMB 35, and the cost is decreased by a half; besides, through the oversea location shipping mode, consumers can wait for only 2-3 days to get the commodities[4]. Decrease the logistics cost, reduce parcel distribution time, and largely improve the competitiveness of cross-border e-business.

Since the cross-border e-business enterprises in Fujian Province are mostly SMEs, the initial input of oversea location and the follow-up maintenance cost are relatively big. Thus, the government should take the lead in cooperating with Fujian cross-border e-business SMEs, and set its own intelligent logistics storage at home and abroad. Orit is applicable to jointly raise funds considering the cross-border e-business enterprises inside the same park and build shared oversea location abroad, so as to decrease logistics cost, and improve the competitive capacity of cross-border e-business in Fujian.

\section{B. Improve cross-border logistics informatization and intelligence level in Fujian}

EBay cross-border e-business service center is settled in Fuzhou and Cainiao intelligent logistics are set in Quanzhou. One of them is a global cross-border e-business giant, and the other is the domestic e-business giant. Fujian cross-border ebusiness can use the technologies and equipment brought thereby, to improve itself cross-border logistics informatization, and intelligence level. For instance, Fujian cross-border ebusiness can create an intelligent database that integrates storage, transportation, distribution, information service, etc. on the basis of intelligent cloud storage system through adopting modernized information technology to process logistics information. Through using this intelligent database, it is applicable to predict the market through cloud calculation data analysis and other methods. Through using such database, conduct the demand prediction of products, product warehouse management, package real-time tracking, plan for the optimal storage and distribution route, and decrease the inventory cost and logistics cost. Besides, it is also applicable to realize the real-time logistics tracking from the ex-warehouse of products to the receiving of consumers through the database, and it is also applicable to further improve the experience degree of clients through giving feedbacks to clients through the system. 
It can provide service to cross-border e-business through the application of modernized information technology. Inform the intelligent database system, to meet the service requested for the daily transaction of cross-border e-business.

\section{Introduce and cultivate professional intelligent logistics talents}

In order to use intelligent logistics to promote the development of cross-border e-business in Fujian, it cannot be separated from professional logistics talents and team to manage the cross-border logistics. Fujian cross-border ebusiness relies on Fujian Free Trade Zone, and has natural geological advantages and political support, and has attracted overseas cross-border e-business giants and domestic crossborder e-business giants while bringing lots of high-end logistics talents and professional team. The government can join hands with enterprises and build an intelligent logistics talent exchange center, to conduct local cross-border e-business training in Fujian and convey intelligent logistics talents, and let enterprises better utilize intelligent logistics to promote cross-border e-business development. Through college cultivation, or the joint school-running of enterprises and colleges, cultivate high-end logistics talents, and convey new blood for enterprises. Irregularly invite experts to conduct professional systematic training for the existing personnel of the enterprise, learn new technologies and how to use the new system. In the face of cross-border e-business, promote intelligent logistics, and provide support in technology, consultation, service and other aspects. Assist in promoting the development of cross-border e-business, and constantly improve the industrial level and influence.

\section{SUMMARY}

To sum up the aforementioned analysis on the cross-border e-business in Fujian, it can be seen that Fujian has natural geological advantages, and with the establishment of Fujian Free Trade Zone, there are various national policies and bonus support, which have brought many advantages to the development of cross-border e-business in Fujian. Intelligent warehouse system can utilize the aforementioned oversea location and cloud warehouse on the basis of realizing intelligent logistics, and then realize the integration of logistics warehouse and distribution, and can make cross-border ebusiness free of the logistics restrictions and grow up fast. Intelligent logistics adopt three-pronged approach and can generally adopt the new logistics mode and the new intelligent logistics system and it will be operated by professional personnel. On one hand, it has broken through the logistics bottleneck of cross-border e-business, and made the crossborder e-business develop fast. Besides, the combination of intelligent logistics and cross-border e-business can be mutually supplemented, and cross-border e-business can better develop with the supplementation of intelligent logistics, and the support of cross-border e-business is also requested to search for the development of intelligent logistics.

\section{REFERENCES}

[1] Fujian Provincial Commission of Economy and Information Technology. Digital Economy, Injecting "Vigor Elements" to New Fujian [EB/OL].http://www.fjetc.gov.cn/zfxxgk/newsInfo.aspx?newsid=11552 0, 2018-04-02

[2] Fujian Provincial People's Government Network. Notice of Fujian Provincial People's Government about Accelerating 9 Measures of Ebusiness Development [EB/OL].http://www.fujian.gov.cn/xw/ztzl/qyjrdd/szfjszfbgtwj/201507/t 20150703_997773.htm,2015-07-02

[3] Xiufeng Song. Analysis on the Future Development of Cross-border Ebusiness Platform in Fujian Free Trade Zone [J]. Journal of Chifeng University (Natural Science Version), 2015, 31 (12): 95-97.

[4] Xiaheng Zhang and Tianshan Ma. Chinese Cross-border E-business Logistics Dilemma and Countermeasure Suggestions [J]. Contemporary Economy \& Management, 2015, 37 (5): 51-54. 